
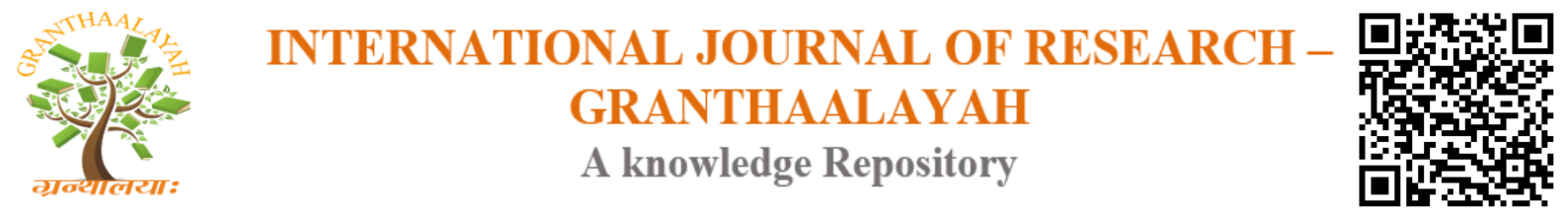

Management

\title{
DOES FINANCIAL PLAN IMPACT INVESTMENT DECISIONS?
}

\author{
FCA Pratibha Chaurasia ${ }^{1}$, Dr. Priyanka Vijay ${ }^{2}$ \\ ${ }^{1}$ Research Scholar, Banasthali University, India \\ ${ }^{2}$ Assistant Professor-FMS-WISDOM, Banasthali University, India
}

\begin{abstract}
Discipline is the bridge between goals and accomplishments and good financial habits bring discipline in financial decision making and have profound impact on the investment choices. This study proposes to study core financial habit of making financial plan adopted by individual investors while doing their investment planning and its impact on the investment preferences and objectives. In this study, survey approach has been adopted using a structured questionnaire with 559 sample size. The study has been taken within the geographical area of Indore and Ujjain district in Madhya Pradesh State of Central India. It has been found from the analysis that financial habits of investors play a crucial role in their investment preferences and objectives. Analysis has been done using Mann Whitney U test.

The results of the research paper would contribute in developing understanding of the impact of financial habits on investment behavior and choices and thus serves an important insight to investors, financial planning professionals and other stakeholders linked to financial planning.
\end{abstract}

Keywords: Financial Habits; Investor; Investment Preference; Objectives; Central India.

Cite This Article: FCA Pratibha Chaurasia, and Dr. Priyanka Vijay. (2017). "DOES FINANCIAL PLAN IMPACT INVESTMENT DECISIONS?." International Journal of Research - Granthaalayah, 5(11), 198-205. 10.29121/granthaalayah.v5.i11.2017.2347.

\section{Introduction}

Nothing is stronger than habits. The strong foundation of financial prosperity can be built on right financial habits. Financial habit of making a financial plan may have profound impact on the quality of financial decisions as it lays down the financial goals and its pathway clearly.

Financial theories have evolved from the ancient times to modern times taking the journey from rationality to finance behavioral theories. The behavior of investor impacts the decision making process and its outcome. Investment decisions are very complicated as many investment options are available in market with different level of risk and returns, tax treatments, cost of transaction etc. A clear financial plan can provide clarity to many important aspects and expectations related to investments. A good financial plan would have several steps to following from assessing the current financial position, identification and setting the financial goals (long term, medium term 
and short term), the investment plan to achieve the set goals based on desired risk and return. The investment planning with a plan will be more result -oriented and suited to the needs of the individual. The plan will be customized based the financial goals and needs.

The research focuses to study the impact of habit of making financial plan on the investment preferences and objectives of the investors. For the research nine different investment avenues are ranked in order of preference by the respondents namely saving bank account, fixed deposit, small saving scheme, life insurance, mutual fund, shares, capital market debt instrument, real estate and gold/silver ranging from traditional products to modern day financial products. To further, study the impact of the habit on the investment objectives of the investors, six objectives namely safety of principal, regular income, capital appreciation, quick returns, tax benefit and ease of liquidity are considered.

The research primary aim is to make investors aware and motivate them towards healthy financial habits and explore the association of financial habits and the selection of investment avenues and investment objectives of the investors.

The knowledge pools of investment theories and researchers have evolved over the time and it is a well-accepted fact that financial behavior and attitudes have a major impact on the financial decision of every individual. Core behaviors impact the financial decisions during the entire lifetime of the individuals.

V.K. Thomas (2005) in his article "Tax Saving Avenues to the Salaried Class" deduced that an optimum plan of saving schemes will generate maximum return and lesser tax burden to the tax payers.

Maheshwari P (2014) in the research paper "Role of Planning in the Financial Decision Making of Individuals" concluded that there is significant difference between various age groups and their financial planning habits. Younger age group 20-30 years did not do proper planning, 30-40 years age group do financial planning of elementary level, investors in age group 40-50 years and 50 years and above make proper financial plan and recorded what is invested and compare planned with actual investments.

Chattopadhyay and Dasgupta (2015) identified factors like age, marital status, gender, monetary planning, income, employment, education have significant impact on the risk tolerance of investors.

As per the $8^{\text {th }}$ Annual Fidelity New Year Resolutions Study 2016, it is found that American's top 3 resolutions for 2017 remain as save, pay down debts and spend less. 50\% of the survey respondents took a financial resolution to save more, $28 \%$ to pay down the debts and $16 \%$ to spend less. Overall $36 \%$ of the respondents plan to make financial resolution in 2017. Among the respondents planning to save more for long term, $64 \%$ want to save for retirement and more that $50 \%$ plan to increase retirement saving. Among the short term saving planners, $72 \%$ need an emergency fund. The past three years of study revealed the positive impact of these financial resolutions as the people who made these resolutions grew more optimistic (52\% strongly felt they would be financially better in 2017), more debt free (45\% were less in debt compared to last 
year) and more financially secure (52\% were in better financial situation as compared to last year). The results of the survey clearly indicate the need of proper financial planning and impact of right financial habits to the financial prosperity.

As per Survey of Financial Behaviors and Financial Habits of Young Working Malaysians 2016, majority of young Malaysians manage their finances poorly. 30\% of the respondents of the survey had no saving. Only $49 \%$ had some form of insurance, $31 \%$ had investments and $69 \%$ had no investments. Retirement planning is considered important but $37 \%$ of the respondents never thought of retirement. About $46.8 \%$ had high debt obligations. $61.3 \%$ of the respondents rated them very poor in managing finances. The survey also revealed that bad financial habits led to difficulty in understanding the financial products and resulted in poor decision making.

As per Manulife Survey (2017) on eight Asian countries on millennial investors, it is found that property and cash are most preferred investment avenues for group of millennial investors in age group 18 to 34 for retirement similar to their parent's pattern of investment. Thus, evident those habits have a profound impact on the investment selection.

As per Australian Financial Attitudes and Behavior Tracker Wave 5 2017, 58\% of Australian reported to be confident in managing money, however $36 \%$ find dealing finances stressful. $79 \%$ of the respondents had a budget. Only $44 \%$ have short-term financial plan and $23 \%$ long term financial plan. Out of the respondents who made a long term plan, 37\% reached some of the financial goals set in the plan. Figure 1.1 depicts the progress of long term planners.

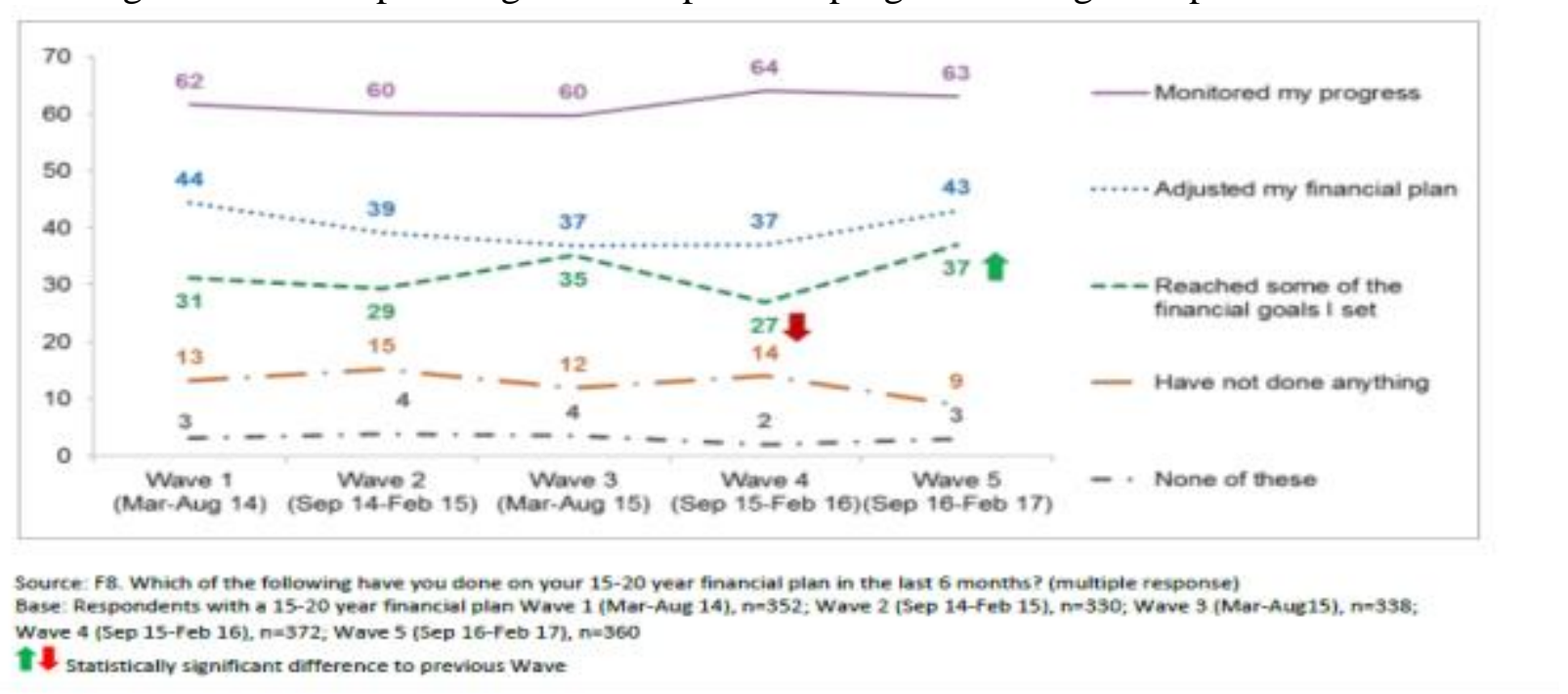

Source: Australian Financial Attitudes and Behavior Tracker Wave 5

Further, only $32 \%$ of the respondents felt confident of their investment ability and understanding risk/return concept. Females (23\%) reported to be less confident in comparison to males (42\%). Also, $21 \%$ of the respondents had no saving.

As per Parents, Kids and Money Survey (2017) conducted by T. Rowe, parents attitude and behaviors are associated with kids' financial habits. Positive money habits of kids are associated with parent's modeling good financial habits. Troubled financial habits are observed when parents model poor financial behavior. The habit of discussing finances by parents make 
financially smart kids. Thus, it is evident financial habits have a strong association to quality of financial decisions.

As per Northwestern Mutual's Annual Planning and Progress Study (2017), Americans having financial advisors feel well-prepared for retirement and more confident. $70 \%$ of respondents using financial advice feel their retirement plan is better designed to meet market ups and down compared to just $30 \%$ of respondents without financial advice. The study suggests that good financial habits are main reason for investors feeling less anxiety about financial matters and managing emergencies.

\subsection{Objectives}

- To study impact of financial plan making habit on the investment preference of the individuals.

- To study association of financial plan habit and the investment objectives of the investors.

\subsection{Hypotheses}

$\mathrm{H} 1$ the investment avenues preferred by the investor are independent of the habit of having a financial plan.

$\mathrm{H} 2$ the investment objectives of investors are independent of the habit of having a financial plan.

\section{Material and Methods}

Research methodology adopted aims to study association of habit of financial planning and the investment preference of the investors and its impact on the investment objectives of the investors. In this study, hypotheses of research problem are tested using Mann Whitney U Test and mean rank method. At an initial stage, the study is conducted based on structured questionnaire to study the financial habits and preferences of diversified set of individual investors. The respondents were furnished with questions on their financial planning behavior and preferences. The target population for the study is investors from Indore and Ujjain district in state of Madhya Pradesh, Central India

\subsection{Sampling Design}

The target respondents include investors from varied backgrounds of age, qualification, occupation, income level, who are active investors and are involved in individual financial planning decisions. Judgmental sampling with a sample size of 559 respondents is used in the research.

\subsection{Data Collection}

The primary data for the study is collected through structured questionnaire containing questions related to the financial habits of individual investors and their preferences and objectives of 
investment. The questionnaire consists of close-ended as well as open ended questions on the financial behavior of individuals. The responses are gathered online or physically through a hard copy. The data collection went for period of seven months during the month of February 2017 to August 2017. Secondary data has been collected from academic research papers, web portals and financial surveys both nationally and internationally.

\section{Results and Discussions}

The distribution of investors based on their habit of making and not making a financial plan is depicted in Table 3.1.

Table 3.1: Distribution of Investors based on the Habit of Financial Plan

\begin{tabular}{|l|l|l|}
\hline \multicolumn{1}{|c|}{ Financial Plan } & \multicolumn{1}{c|}{ Frequency } & \multicolumn{1}{c|}{ Percent } \\
\hline Yes & 281 & 50.3 \\
\hline No & 278 & 49.7 \\
\hline Total & 559 & 100.0 \\
\hline
\end{tabular}

Out of the total 559 respondents, 50.3\% make a financial plan and $49.7 \%$ denied of making any financial plan.

Each investor has an investment portfolio comprising of preferred investment instruments. Under the study investors preference of the nine investment avenues namely saving account, fixed deposit, small saving scheme, life insurance, mutual fund, shares, capital market debt instruments, real estate and gold/silver were ranked in order of preference from top rank as 1 and lowest as 9. The table 3.2 and table 3.3 depict the ranking preference of investors based on their habit of making the financial plan and not having a financial plan.

Table 3.2: Ranking Preference of Investment Avenues for Investors making Financial Plan

\begin{tabular}{|l|l|l|l|l|l|l|l|l|l|l|}
\hline \multirow{2}{*}{ Rank Factor } & \multicolumn{9}{|c|}{ Number of Investors } \\
\cline { 2 - 13 } & $\mathbf{1}$ & $\mathbf{2}$ & $\mathbf{3}$ & $\mathbf{4}$ & $\mathbf{5}$ & $\mathbf{6}$ & $\mathbf{7}$ & $\mathbf{8}$ & $\mathbf{9}$ & Total \\
\hline Saving Account & 58 & 16 & 18 & 16 & 30 & 22 & 24 & 41 & 56 & 281 \\
\hline Fixed Deposit & 35 & 74 & 29 & 24 & 24 & 16 & 33 & 32 & 14 & 281 \\
\hline Small Saving Scheme & 18 & 30 & 81 & 34 & 24 & 22 & 30 & 32 & 10 & 281 \\
\hline Life Insurance & 23 & 21 & 34 & 70 & 35 & 42 & 22 & 6 & 28 & 281 \\
\hline Mutual Fund & 64 & 38 & 20 & 24 & 65 & 24 & 14 & 14 & 18 & 281 \\
\hline Shares & 36 & 38 & 24 & 24 & 16 & 58 & 27 & 19 & 39 & 281 \\
\hline Capital Market debt & 4 & 6 & 26 & 22 & 26 & 42 & 80 & 37 & 38 & 281 \\
\hline Real Estate & 28 & 32 & 25 & 29 & 28 & 28 & 23 & 66 & 22 & 281 \\
\hline Gold/Silver & 15 & 26 & 24 & 38 & 33 & 27 & 28 & 34 & 56 & 281 \\
\hline
\end{tabular}


Table 3.3: Ranking Preference of Avenues for Investors not making Financial Plan

\begin{tabular}{|l|l|l|l|l|l|l|l|l|l|l|}
\hline \multirow{2}{*}{ Rank Factor } & \multicolumn{9}{|c|}{ Number of Investors } \\
\cline { 2 - 14 } & $\mathbf{1}$ & $\mathbf{2}$ & $\mathbf{3}$ & $\mathbf{4}$ & $\mathbf{5}$ & $\mathbf{6}$ & $\mathbf{7}$ & $\mathbf{8}$ & $\mathbf{9}$ & Total \\
\hline Saving Account & 79 & 19 & 18 & 44 & 34 & 14 & 25 & 14 & 31 & 278 \\
\hline Fixed Deposit & 46 & 81 & 40 & 34 & 20 & 20 & 12 & 15 & 10 & 278 \\
\hline Small Saving Scheme & 25 & 36 & 77 & 26 & 25 & 30 & 27 & 18 & 14 & 278 \\
\hline Life Insurance & 14 & 34 & 38 & 69 & 30 & 38 & 11 & 24 & 20 & 278 \\
\hline Mutual Fund & 32 & 19 & 17 & 20 & 51 & 45 & 32 & 42 & 20 & 278 \\
\hline Shares & 10 & 11 & 19 & 6 & 28 & 61 & 40 & 38 & 65 & 278 \\
\hline Capital Market debt & 12 & 14 & 19 & 22 & 27 & 24 & 88 & 44 & 28 & 278 \\
\hline Real Estate & 38 & 34 & 14 & 14 & 40 & 20 & 22 & 53 & 43 & 278 \\
\hline Gold/Silver & 22 & 30 & 36 & 43 & 23 & 26 & 21 & 30 & 47 & 278 \\
\hline
\end{tabular}

Further, six investment objectives of the investors are studied under this research namely safety of principal, regular income, capital gain, quick returns, tax benefit and liquidity which are ranked in order of preference from top rank 1 to lowest rank 6. The table 3.4 depicts the distribution of investors based on their habit of having and not having financial plan and the preference towards investment objectives.

Table 3.4: Ranking Preferences of Investment Objectives based on Financial Plan Habit

\begin{tabular}{|c|c|c|c|c|c|c|c|}
\hline Objective & Rank 1 & Rank 2 & Rank 3 & Rank 4 & Rank 5 & Rank 6 & Total \\
\hline Safety of Yes & 123 & 42 & 44 & 26 & 24 & 22 & 281 \\
\hline Principal & 147 & 48 & 28 & 20 & 19 & 16 & 278 \\
\hline Total & 270 & 90 & 72 & 46 & 43 & 38 & 559 \\
\hline Regular & 18 & 94 & 35 & 44 & 56 & 34 & 281 \\
\hline Income & 36 & 107 & 40 & 37 & 38 & 20 & 278 \\
\hline Total & 54 & 201 & 75 & 81 & 94 & 54 & 559 \\
\hline Capital Gain Yes & 81 & 55 & 80 & 27 & 24 & 14 & 281 \\
\hline $\mathrm{NO}$ & 47 & 58 & 102 & 38 & 23 & 10 & 278 \\
\hline Total & 128 & 113 & 182 & 65 & 47 & 24 & 559 \\
\hline Quick & 14 & 20 & 28 & 82 & 46 & 91 & 281 \\
\hline Return & 18 & 18 & 30 & 84 & 43 & 85 & 278 \\
\hline Total & 32 & 38 & 58 & 166 & 89 & 176 & 559 \\
\hline Tax Benefit Yes & 33 & 37 & 55 & 44 & 78 & 34 & 281 \\
\hline $\mathrm{NO}$ & 20 & 25 & 32 & 53 & 100 & 48 & 278 \\
\hline Total & 53 & 62 & 87 & 97 & 178 & 82 & 559 \\
\hline Liquidity & 12 & 37 & 39 & 56 & 51 & 86 & 281 \\
\hline $\mathrm{NO}$ & 10 & 24 & 44 & 46 & 55 & 99 & 278 \\
\hline Total & 22 & 61 & 83 & 102 & 106 & 185 & 559 \\
\hline
\end{tabular}

To test the hypotheses, Mann- Whitney U Test is applied. The table 3.5 depicts results of MannWhitney $U$ test in relation to habit of financial planning and preference towards investment avenues. 
Table 3.5: Mann- Whitney U Test: Financial Plan and Investment Preference

\begin{tabular}{|c|c|c|c|c|c|c|c|c|c|}
\hline & $\begin{array}{c}\text { Saving } \\
\text { A/C }\end{array}$ & \begin{tabular}{|c|} 
Fixed \\
Deposit
\end{tabular} & \begin{tabular}{|c|} 
Small \\
Saving \\
Scheme
\end{tabular} & \begin{tabular}{|c|} 
Life \\
Insurance
\end{tabular} & $\begin{array}{l}\text { Mutual } \\
\text { Fund }\end{array}$ & Shares & $\begin{array}{c}\text { Capita } \\
\text { Marke } \\
\text { debt }\end{array}$ & \begin{tabular}{|c|c|} 
& Real \\
tEstate
\end{tabular} & $\begin{array}{l}\text { Gold/ } \\
\text { Silver }\end{array}$ \\
\hline \begin{tabular}{|l} 
Mann- \\
Whitney U
\end{tabular} & 30713 & 33164 & \multicolumn{2}{|c|}{36840.50038068} & \multicolumn{3}{|c|}{27858.50026999 .50037852} & 37861 & 35008.500 \\
\hline Wilcoxon W & 69494 & 71945 & \multicolumn{2}{|c|}{75621.50076849} & \multicolumn{3}{|c|}{67479.50066620 .50076633} & 77482 & 73789.500 \\
\hline$Z$ & -4.424 & -3.134 & -1.179 & -.525 & -5.925 & -6.384 & -.644 & -.633 & -2.138 \\
\hline $\begin{array}{l}\text { Asymp. Sig. } \\
\text { (2-tailed) }\end{array}$ & .000 & .002 & .238 & .599 & .000 & .000 & .520 & .527 & .032 \\
\hline
\end{tabular}

The results of Mann- Whitney $U$ test suggest that habit of financial planning has significant association with investment avenues of saving bank account, fixed deposit, mutual fund, shares and gold/silver as the asymptotic significance is less that .05 and hence the null hypothesis is rejected and alternative hypothesis is accepted.

However, results of Mann- Whitney U test further suggest that financial plan habit has no significant association with investment avenues of small saving scheme, life insurance, capital market debt instruments and real estate and hence the null hypothesis is accepted.

To test the hypothesis of association between habit of financial plan and investment objectives, Mann Whitney U test is applied as depicted in table 3.6.

Table 3.6: Mann- Whitney U Test: Financial Plan and Investment Objective

\begin{tabular}{|l|l|l|l|l|l|l|}
\hline & $\begin{array}{c}\text { Safety of } \\
\text { Principal }\end{array}$ & $\begin{array}{c}\text { Regular } \\
\text { Income }\end{array}$ & $\begin{array}{c}\text { Capital } \\
\text { Gain }\end{array}$ & $\begin{array}{c}\text { Quick } \\
\text { Returns }\end{array}$ & Tax Benefit & Liquidity \\
\hline Mann-Whitney U & 34641.500 & 32314.000 & 34643.500 & 37848.500 & 32117.500 & 36091.500 \\
\hline Wilcoxon W & 73422.500 & 71095.000 & 74264.500 & 76629.500 & 71738.500 & 75712.500 \\
\hline Z & -2.467 & -3.641 & -2.381 & -.655 & -3.723 & -1.598 \\
\hline $\begin{array}{l}\text { Asymp. Sig. (2- } \\
\text { tailed) }\end{array}$ & .014 & .000 & .017 & .512 & .000 & .110 \\
\hline \begin{tabular}{l} 
a. Grouping Variable: Fplan \\
\hline
\end{tabular}
\end{tabular}

The results of Mann- Whitney $U$ test suggest that habit of financial planning has significant association with investment objectives of safety of principal, regular income, capital gain and tax benefit as the asymptotic significance is less that .05 and hence the null hypothesis is rejected and alternative hypothesis is accepted.

However, results of Mann- Whitney U test further suggest that financial plan habit has no significant association with investment objective of quick return and liquidity and hence the null hypothesis is accepted.

\section{Conclusion}

The research study has deduced that financial planning habit has a significant association both with the choice of the investments and investment objectives of the investors. It is further 
deduced that preference to investment objective of safety of principal, regular income, capital growth and tax benefit of investors have significant difference among investors with habit of making and not making financial plan. However, investment objective of quick returns and liquidity has no significant relationship with the habit of making/not making financial plan. Also, the investment preference towards saving account, fixed deposit, mutual funds, shares and gold/silver of investors have significant difference among investors making and not making financial plan. However the investment avenues of small saving scheme, life insurance, capital market debt instruments and real estate does not have significant association to the habit of making/not making financial plan.

\section{References}

[1] Maheshwari P (2014), “ ROLE OF PLANNING IN THE FINANCIAL DECISION MAKING OF INDIVIDUALS", International Journal of Business and Administration Research Review, Vol. 3, Issue 6, July-Sep, 2014 pp.88-94

[2] Sandip Chattopadhyay and Ranjan Dasgupta (2015), "DEMOGRAPHIC AND SOCIAECONOMIC IMPACT ON RISK ATTITUDES OF THE INDIAN INVESTORS- AN EMPIRICAL STUDY”, Asian Economic and financial Review, Volume 05; Number 04, Pg. 601623

[3] Thomas V.K. (2005), "TAX SAVING AVENUES TO THE SALARIED CLASS", Southern Economist, March 15, 2005, pp. 31-32.

[4] $8^{\text {th }}$ Annual Fidelity New Year Resolutions Study (2016), https://www.fidelity.com/aboutfidelity/individual-investing/8th-fidelity-resolution-study-reveals-americans-feel-better-financialshape

[5] Australian Financial Attitudes and Behavior Tracker Wave 5 (2017), http://www.financialliteracy.gov.au/research-and-evaluation/financial-attitudes-and-behaviourtracker

[6] Manulife Survey (2017) http://www.todayonline.com/business/asias-millennial-investors-preferproperty-and-cash-just-their-parents-says-manulife-survey

[7] Northwestern Mutual's Annual Planning and Progress Study (2017), news.northwesternmutual.com/.../2017-Planning-Progress-The-Middle-Class.pdf

[8] Survey of Financial Behaviors and Financial Habits of Young Working Malaysians 2016, https://mfpc.org.my/survey-financial-behaviours-financial-habits-young-working-malaysians/

[9] T. Rowe (2017), "T. ROWE PRICE: PARENTS ARE LIKELY TO PASS DOWN GOOD AND BAD FINANCIAL HABITS TO THEIR KIDS", https://www.prnewswire.com/news-releases/trowe-price-parents-are-likely-to-pass-down-good-and-bad-financial-habits-to-their-kids300428414.html

*Corresponding author.

E-mail address: pratibhadc@ gmail.com 